DOI: https://dx.doi.org/10.24093/awej/vol12no3.7

\title{
Critical Thinking in Algerian Secondary School EFL Classes: Expectations and Reality
}

\author{
Meriem Baghoussi \\ Department of English, Faculty of Letters and Languages \\ University of Abdelhamid Ibn Badis, Mostaganem, Algeria \\ Email: meriembaghoussi@gmail.com
}

Received: 4/1/2021

Accepted: 8/26/2021

Published: 9/24/2021

\begin{abstract}
The Algerian educational system is competency-based; therefore, it focuses on developing learners' competencies and skills through a learner-centered methodology that fosters autonomy. To help teachers apply such methodology, the English syllabus designers recommend using Project-Based Learning, active learning, and problem-solving strategies to help learners develop $21^{\text {st }}$-century skills and communicate effectively, collaborate, and think critically and creatively. However, those methods and strategies are absent in classrooms, and therefore critical thinking is not promoted. In this context, two questions are raised to affirm this hypothesis. (1) To what extent do teachers respect the syllabus designers' recommendations? (2) Why do teachers avoid using the recommended methods and strategies? To investigate those questions and achieve the aim of this research, the researcher carried out an in-depth quantitative analysis of 30 anonymous classroom observation reports written by a certified English teacher trainer. To address the qualitative aspect of the research, the researcher held a semi-structured interview with the same teacher trainer. The reports that were examined contained 150 comments on teachers' classroom practices and assessment methodologies. The results showed that English teachers partially respect the syllabus designers' recommendations. Besides, the teachers' methods, classroom practices, and assessment approaches are mainly based on direct instruction and language content acquisition rather than on reflective and problem-solving learning; therefore, they are not conducive to implementing and developing learners' critical thinking. The conclusion drawn from the data analysis of the current research is that teachers' hesitance to use the recommended pedagogical approach and methods is due to some hindrances faced by teachers, namely classrooms overcrowdedness, the content-based baccalaureate exam and lack of time due to the lengthy English programs.
\end{abstract}

Keywords: Algerian secondary school EFL classes, competency-based, critical thinking, Project-Based Learning, $21^{\text {st }}$-century skills

Cite as: Baghoussi, M. (2021). Critical Thinking in Algerian Secondary School EFL Classes:

Expectations and Reality . Arab World English Journal, 12 (3) 97-110.

DOI: https://dx.doi.org/10.24093/awej/vol12no3.7 


\section{Introduction}

The quality of our lives depends considerably on the quality of our thinking. Humans have exceptional cognitive abilities that enable them to think; however, not all thinking results in successful outcomes. Therefore, the ability to think critically helps individuals use inductive and deductive reasoning to make inferences, analyze arguments, judge and evaluate, make decisions, and solve all kinds of problems. Such skills, and especially critical thinking, are now required and highly valued in almost every field. That is why our learners should possess those skills to think critically, analytically, and creatively. Those skills also help them to communicate and collaborate effectively with others to face modern world challenges. To reach that aim and help our learners develop such skills, the designers of the present secondary school English syllabuses recommend using the learner-centered approach, project pedagogy, active learning and problemsolving strategies to foster learners' critical thinking. In this context, the first, second and thirdyear secondary-school English syllabuses state that the teaching of English in Algeria involves the acquisition of linguistic and communicative competencies and the development of a critical mind (MNE, 2005a; 2005b; 2006).

The teaching of English in Algeria involves the acquisition of linguistic, communicative and transversal skills of a methodological, technological, cultural, social nature in the pupil, such as the development of a critical mind and analysis, attachment to our national values, respect for universal values based on respect for oneself and others, tolerance and openness to the world.

In this context, the present research investigates the current classroom practices to determine whether they are conducive to learners' critical thinking development as expected and recommended by the syllabus designers. It also aims to raise the Algerian English teachers' awareness of the necessity of critical thinking skills in facing $21^{\text {st }}$-century challenges. To reach that aim, the researcher put forward a hypothesis stipulating that the active learning methods and strategies that help foster learners' critical thinking are absent in classrooms.

To confirm the hypothesis mentioned above, the researcher relied on two research methods: quantitative and qualitative. The researcher received and analyzed anonymous classroom reports written by an English teacher trainer during his classroom visits for the quantitative research. To dig deeper into the topic, the researcher interviewed the same teacher trainer. The results of both tools confirmed the hypothesis stated previously and revealed that the scarcity of those active learning methods and strategies is due to the prevalence of teachercenteredness. Such a classroom environment is instruction and content-based because teachers are "on their feet in the front of the room with eyes open, asking questions, making points, gesturing, writing key ideas on the board, encouraging, correcting, demonstrating, and so forth," (Schug, 2003, as cited in Leming, Ellington \& Porter-Magee, p.94). Therefore, it does not offer the necessary ingredients for enhancing critical thinking, such as learners' autonomy, collaboration, communication and creativity. The current study results showed that teachers face some problems that prevent them from adopting active learning methods and strategies that promote critical thinking. In addition, the results of the two research tools used helped answer the two research questions raised in this study and revealed that classrooms overcrowdedness, lack of time due to the lengthy English programs and the nature of the baccalaureate exam (language/content-based) prevent teachers from adopting active learning methods and strategies and therefore hinder critical thinking enhancement. 


\section{Literature Review}

\section{Critical Thinking Definition}

Though critical thinking is widely regarded as crucial, no clear-cut definition has been acknowledged, and its precise significance and educational implications remain ambiguous. In this context, Fasko (2003) stated that "there is no consensus on a definition of critical thinking" (p.8). Several definitions of critical thinking have been used in the literature and other types of thinking, namely reflective thinking, critical analysis, rational thinking, and higher-order thinking. For some scholars, "critical thinking is one of the most frequently discussed higher order skills, believed to play a central role in logical thinking, decision making, and problem solving" (Liu, Frankel \& Roohr, 2014, p.1). Other theorists regarded critical thinking as a multidimensional skill that humans must learn and practice to perform well. From another perspective, Paul (1993) emphasized the cognitive and metacognitive components of critical thinking and defined it as "thinking about your thinking while you're thinking to make your thinking better" (p.91). For Crowl, Kaminsky and Podell (1997), critical thinking is an essential factor in metacognitive processes; whereas, Halpern (1996) considered it as the kind of "thinking that is purposeful, reasoned, and goal directed - the kind of thinking involved in solving problems, formulating inferences, calculating likelihoods, and making decisions" (p.5). Scriven and Paul (1987) gave a detailed definition. They state that "critical thinking is the intellectually disciplined process of actively and skillfully conceptualizing, applying, analyzing, synthesizing, and/or evaluating information gathered from, or generated by, observation, experience, reflection, reasoning, or communication, as a guide to belief and action" (p.1).

In this context, Bloom, Englehart, Furst, Hill and Krathwohl (1956) did not define critical thinking, but they elaborated a taxonomy in which they presented and described the main cognitive categories: Knowledge, Comprehension, Application, Analysis, Synthesis, and Evaluation. That taxonomy of learning objectives is considered a hierarchical approach to critical thinking since it classifies thinking into two levels: higher-order and lower-order thinking skills. The following paragraph will give more details about Bloom's Taxonomy. It is worth noting that the analysis of the research tool data of this study relied on Bloom's classification of thinking skills.

\section{Critical Thinking and Bloom's Taxonomy}

Learning is a complex process that is managed by the brain. That complexity has led to the emergence of various definitions of learning. According to Smith (1962), learning is "the acquisition of new behavior or the strengthening or weakening of old behavior as the result of experience" (p.260). Ray Loree (1965) defined it "as a relatively permanent change of behavior that occurs as a result of experience or practice" (pp.193-194). That change in behavior keeps developing thanks to specific thinking skills that help 'learners' transform their experience into learning. However, the fact of knowing the 'what' does not help us to think critically and solve problems; therefore, we need to know the 'how' and the 'why' to reinforce and develop our cognitive potential and be ready and able to think critically and act creatively to face life challenges positively and successfully. Dr. Benjamin Bloom proposed a hierarchy of the thinking process known today as Bloom's Taxonomy of Learning Objectives to foster such skills among learners. That hierarchy categorizes learners' thinking skills and ranges them from the most basic skill (recalling) to the most complex one (evaluation). ("Bloom's Taxonomy", 2019). Therefore, the original version of Bloom's Taxonomy classified the skills as follows: knowledge, 
comprehension, application, analysis, synthesis, and evaluation. In 2001, Anderson and Krathwohl proposed a revised version of the original Bloom's taxonomy in which the nouns were transformed into verbs: remember, understand, apply, analyze, evaluate, and create. The first three skills - remember, understand, apply- were categorized as Lower Order Thinking Skills (LOTS), and the three other skills belonged to the Higher Order Thinking Skills (HOTS). This perception opened other perspectives for the teaching-learning processes. Bloom's Taxonomy has helped teachers understand the fluctuating levels of cognitive, psychomotor, and affective processes of learners. It helped them adjust instruction to enhance and develop critical thinking among learners. Teachers now can establish measurable learning objectives for their lessons and design tasks accordingly to help learners develop their critical thinking. It is worth noting that using a task-based approach in conjunction with classroom projects is an effective way to improve critical thinking, concretize learning, and enable learners to do what is necessary to achieve the desired outcome.

\section{Critical Thinking and Other Concepts}

The relationship of critical thinking with other concepts depends on how one defines the term. Although there are contests concerning the definition of critical thinking, it is widely accepted that it is a unique fundamental concept embedding high-quality thinking that is directed towards a specific goal: solving problems and making decisions. Many researchers have linked critical thinking to other concepts commonly recognized as fundamental elements in the twentyfirst century. To limit the scope of the current research, the researcher will discuss a few of them, namely metacognition, intelligence and creative thinking.

\section{Critical Thinking and Metacognition}

When individuals use cognitive skills or adequate strategies to increase their chance of getting the target outcome, they pave the way for critical thinking. In this context, Schoen (1983) asserted that metacognition is a vital ingredient for critical thinking skills enhancement. Therefore, the enhancement of learners' critical thinking depends a lot on their metacognitive capacities. To show the link between metacognition and critical thinking, Schoen (1983) added that:

A successful pedagogy that can serve as a basis for the enhancement of thinking will have to incorporate ideas about the way in which learners organize knowledge and internally represent it and the way these representations change and resist change when new information is encountered. (p.87)

In this quotation, he affirms that the development of thinking depends on the internal process of organizing knowledge. That process can be an aspect of metacognition. Furthermore, Halonen (1995) defined metacognition as the ability to assess the quality of critical thinking. Similarly, Halpern (1998) described metacognition as the ability to use knowledge to monitor and develop thinking skills. In a four-part model, she presented metacognition and critical thinking together. According to her, when learners are engaged in critical thinking, they need to check their metacognitive process carefully, scrutinize their thinking, check their progress, ensure exactness, and make decisions about time and effort use. "This implies evidently that critical thinking is a product of metacognition which provides a direction in the prediction of the two variables" (Magno, 2010, p.138). For Choy and Cheah (2009), metacognition and critical thinking are 
interconnected. Their study found that critical thinking occurs successfully when a teacher provides learners with some specific cognitive and metacognitive strategies.

Although psychologists and scholars have various constructs concerning critical thinking and metacognition, considering metacognition as a component of critical thinking, or critical thinking as a component of metacognition, it is worth saying that both processes are so inextricably linked that one cannot exist without the other.

\section{Critical Thinking and Intelligence}

Before discussing the difference between intelligence and thinking skills, it is necessary to understand the nature and definition of intelligence. It is also imperative to identify whether intelligence could make people critical thinkers or whether the fact of being a critical thinker makes people more intelligent.

Despite extensive research and endless debates on intelligence, there is no specific or universal definition of this ability; intelligence is considered one of the most important and controversial topics in psychology. In this context, Halpern (2014) asserted that "it is a basic topic in thinking because intelligence is the "stuff" of which thought is made" (p.29). Herrnstein and Murray (1994) considered intelligence as a "cognitive ability". For Gardner (1993), intelligence is "the ability to solve problems or to create products that are valued within one or more cultural settings". In the same perspective, Gottfredson (1997) gave a more detailed definition:

[Intelligence] involves the ability to reason, plan, solve problems, think abstractly, comprehend complex ideas, learn quickly and learn from experience. It is not merely book learning, a narrow academic skill, or test-taking smarts. Rather it reflects a broader and deeper capability for comprehending our surroundings - 'catching on', 'making sense of things, or 'figuring out' what to do. (p.13)

Compared to the intelligence models based on psychometric properties of common intelligence, Halpern and Butler (2020) agree that critical thinking is the best model that helps address realworld problems.

Those reflections, once again, demonstrate the close relationship critical thinking has with intelligence. Both skills share almost the same features: problem-solving, deep thinking, and comprehension of real-life issues.

\section{Critical Thinking and Creative Thinking}

The definition of the two concepts also raises some controversies. Since there is no consensus on the definitions of these concepts, the literature shows that both of them are distinguishable. To clarify the relationship between the two concepts, Beyer (1987) provided a detailed comparison:

Whereas creative thinking is divergent, critical thinking is convergent; whereas creative thinking tries to create something new, critical thinking seeks to assess worth or validity in something that exists; whereas creative thinking is carried on by violating accepted principles, critical thinking is carried on by applying accepted principles. Although 
creative and critical thinking may very well be different sides of the same coin, they are not identical. (p.35)

This comparison shows, to some extent, the divergence in cognitive development between critical and creative thinking.

From another perspective, Fisher (2002) confirmed that both thoughts are important for the thinking process. He also stated that creative thinking is required to create new elements; however, critical thinking is required to judge the new elements created. Forrester (2008) supported Fisher's view and mentioned that "learners need to think in both creative and critical ways and therefore to teach or encourage one style of thinking only may be counter-productive. Instead, an approach is needed which can combine critical and creative thinking" (p.101).

To that end, both creative and critical thinking skills are crucial to efficient thinking; therefore, teachers should integrate them into their lesson plans and classroom practice. If they do, they will ensure life-long learning for learners and effective professional growth for themselves.

\section{Methods}

The present paper embraced a quantitative and qualitative research method for collecting and analyzing the data to assess teachers' classroom practices in connection with critical thinking enhancement among learners. To address this research problem and collect the required information, the researcher received 30 anonymous classroom-observation reports written by a teacher trainer and held a semi-structured interview with him.

\section{Participants}

The participants concerned were 30 active secondary-school English teachers and an experienced English teacher trainer. The teachers whose reports were analyzed were from different schools in Mostaganem city. Their experience varied from five to twenty years of teaching. Their students belonged to first, second, and third-year levels, from different streams: science, mathematics and management, literary, and foreign languages. The trainer's classroom observation reports were dated from March to May 2020.

\section{Instruments}

To conduct the research, the researcher used two tools. Thirty anonymous classroom observation reports were received from a certified English teacher trainer. Those reports contained information about teachers' classroom teaching and assessment methodologies and practices. A semi-structured interview was held with the same teacher trainer to get more details to address the research problem.

The analyzed reports contained 150 comments the teacher trainer wrote during his visits to the observed classrooms. The reports are structured as shown in the table below: 
Arab World English Journal (AWEJ) Volume 12. Number 3. September 2021

Critical Thinking in Algerian Secondary School EFL Classes

Baghoussi

Table 1. The reports sections

\begin{tabular}{|l|l|}
\hline & \multicolumn{1}{c|}{ Section Content } \\
\hline Section 1 & Teacher's personal and academic information; \\
\hline Section 2 & The classroom environment and students' level and number; \\
\hline Section 3 & The instructions of the tasks teachers dealt with in class; \\
\hline Section 4 & $\begin{array}{l}\text { The comments of the teacher trainer on the teacher's methodology, classroom practice and types } \\
\text { of assessment; }\end{array}$ \\
\hline Section 5 & The teacher trainer's general conclusion. \\
\hline
\end{tabular}

\section{Results}

Classroom Observation Reports

Teacher's Personal and Academic Information

Since the teachers' names and gender were anonymous, the only information the researcher could get from Section one was related to the participants' age, degrees and experience. They were aged between 25 and 40. Most (84\%) of them held a Master's degree, and $16 \%$ had a Bachelor of Arts degree in English. Their teaching experience varied between four and twenty-three years.

\section{Classrooms Environment, Students' Numbers, Levels and Streams}

From the analysis of the information in the second section of the reports, the researcher inferred that all of the classrooms visited by the teacher trainer contained aligned rows of tables facing the board. Information about the observed classrooms environment and population is provided in the table below.

Table 2. Reports description of the observed classrooms environment and population

\begin{tabular}{|l|c|c|c|c|c|c|}
\hline \multirow{2}{*}{ Classrooms Environment } & $\begin{array}{c}\text { Students' } \\
\text { Numbers }\end{array}$ & \multicolumn{2}{|c|}{ Students' Levels } & \multicolumn{3}{|c|}{ Students' Streams } \\
\hline $\begin{array}{l}\text { Aligned rows of tables } \\
\text { facing the board }\end{array}$ & $20-36$ & $1 \mathrm{st}$ & 2 nd & 3 rd & $\begin{array}{c}\text { Common } \\
\text { Streams }\end{array}$ & $\begin{array}{c}\text { literary \& foreign } \\
\text { languages }\end{array}$ \\
\cline { 3 - 7 } & 20 & $55 \%$ & $30 \%$ & $15 \%$ & $60 \%$ & $40 \%$ \\
\hline
\end{tabular}

As shown in Table two, the number of students in those classrooms varied between 20 and 36. Most (55\%) of the reports were associated with first-year students, 30\% belonged to second-year classes, and $15 \%$ were linked to third-year classes. $60 \%$ of the students belonged to the common streams: science, mathematics and management; whereas, $40 \%$ were from literary and foreign languages streams.

\section{The Lessons Tasks Instructions and Questions}

In the third section, the reports enclose 90 tasks instructions and questions as worded by the observed teachers during the lessons presentations and recorded by the teacher trainer during his visits. Each report contains between two to four questions/tasks dealt with during the lessons. $96 \%$ of the questions used in the tasks and recorded in the reports were reference questions; however, only a few (04\%) were inference-based. To analyze the tasks, instructions, and questions of lessons deeply, the researcher relied on Bloom's Taxonomy and used it as a scale to classify those questions according to their degree of relevance to the inducement and 
development of Higher-Order Thinking Skills (HOTS). The following table summarizes the results of the analyzed questions:

Table 3. Questions/instructions provoking higher-order thinking skills

\begin{tabular}{|l|l|c|c|}
\hline \multirow{3}{*}{ Skill Category } & \multirow{2}{*}{ Questions... } & $\begin{array}{c}\text { Number of Tasks } \\
/ 90\end{array}$ & Percentage \\
\hline \multirow{3}{*}{ HOTS } & provoking analysis & 01 & $01 \%$ \\
\cline { 2 - 4 } & provoking synthesis & 02 & $02 \%$ \\
\cline { 2 - 4 } & provoking evaluation & 01 & $01 \%$ \\
\hline \multirow{3}{*}{ LOTS } & provoking application & 18 & $20 \%$ \\
\cline { 2 - 4 } & provoking comprehension & 14 & $16 \%$ \\
\cline { 2 - 4 } & provoking knowledge & 54 & $60 \%$ \\
\hline
\end{tabular}

The table above reveals that the questioning type used by teachers in their classrooms was mainly based on rote recall. Those questions push learners to memorize a large amount of information and duplicate it when the teacher asks them during lessons and exams. Such a way of teaching privileges the acquisition of the Lower-Order Thinking Skills (LOTS) to the enhancement and exploitation of the HOTS. Therefore, learners are rarely asked to express their opinions and back them up with reasonable evidence, and they are not instructed to justify, judge and assess their thoughts. In such an environment, teachers' questions and instructions do not provoke curiosity and encourage learners to use their HOTS to solve problems. Inadequate questioning, therefore, is another evidence of the scarcity of critical thinking enhancement and use in classrooms.

\section{The Teacher Trainer's Comments on the Classroom Practices}

The fourth section of the classroom observation reports enclosed 120 comments on the teachers' methodology, types of lessons, and assessment dealt with during the teacher trainer's visits. The lessons presented were related to reading comprehension, speaking, writing, and language outcomes.

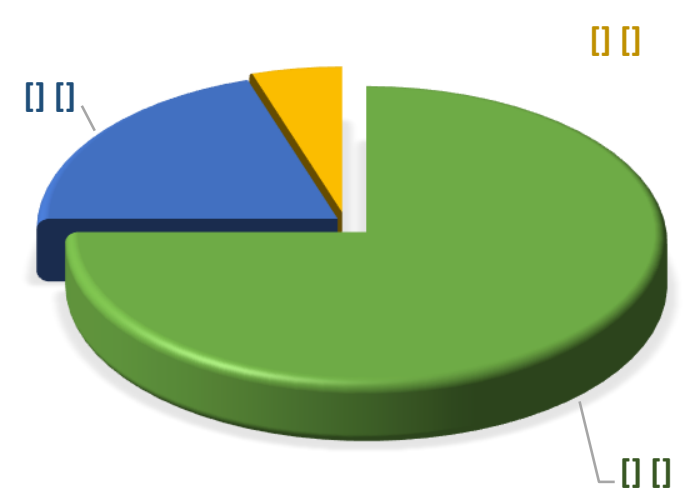

Figure 1. The contents of the presented lessons

The figure above shows that the majority (75\%) of the lessons mentioned in the reports were about language components in which teachers used the coursebooks texts to introduce the embedded grammatical structures, vocabulary, pronunciation and spelling items. Some (20\%) 
lessons were related to reading comprehension, where learners were asked to read the coursebook texts and answer the related questions. However, few (05\%) lessons with their associated activities were about speaking and writing.

The analysis of the comments in the teacher trainer's reports uncovered the methods, strategies and assessment types teachers used during their classroom practice. The following table details the methods adopted by teachers to present their lessons, activities, and the types of assessment tasks teachers used in classrooms.

Table 4. Teachers' classroom practices, teaching methodology, strategies, and assessment

\begin{tabular}{|l|c|c|}
\hline \multicolumn{1}{|c|}{ Classroom Practices, Methods, Strategies and Assessment } & $\begin{array}{c}\text { Number of Comments } \\
/ 120\end{array}$ & Percentage \\
\hline Teachers' omnipresence. & 108 & $90 \%$ \\
\hline Lecturing: talking-time frequency. & 96 & $80 \%$ \\
\hline Content/grammar-based lessons. & 90 & $75 \%$ \\
\hline Communicative tasks: dialogues, debates and role-plays. & 17 & $14 \%$ \\
\hline $\begin{array}{l}\text { Creative and problem-solving tasks: projects presentations, } \\
\text { puzzles and challenging games. }\end{array}$ & 04 & $03 \%$ \\
\hline Assessment & 84 & $70 \%$ \\
\hline
\end{tabular}

The results show that teachers' omnipresence $(90 \%)$ in class and their talking time frequency (80\%) are the most occurred comments in the reports. This implies that the teacher-centered approach is used most of the time in classrooms. Within the comments related to the teachers' omnipresence and lecturing, the trainer raised the teachers' awareness on the drawbacks of such a methodology on learners' learning and performance through concrete examples. Among those drawbacks, the comments cited learners' passivity, participation scarcity, lack of collaboration and creativity in addition to the teachers' excess of close-ended questioning.

Besides, $75 \%$ of the reports referred to the predominance of the content/grammar-based teaching approach in the observed classrooms. However, in some (14\%) comments, the teacher trainer advised teachers to use a mixture of reference-inference, problem-solving and communicative tasks to reduce the use of content and grammar-based methodology and allow learners to collaborate and develop their communication, creativity and critical thinking skills. Few (3\%) comments, however, were about the misuse of problem-solving and active-learning activities. Those comments were given to the concerned teachers as suggestions to help them exploit those activities efficiently.

Many (70\%) reports contained comments about teachers' tests and exams design and marking. The analysis of those comments revealed that the tests and exams were mainly contentbased, requiring learners to replicate the language forms and structures they learned. Nearly all the questions used belonged to the LOTS category; only a few of them contained inference and problem-solving questions at the level of texts interpretations and paragraph/essay writing. Therefore, in this case, the current assessment models rely on language structure rather than on authentic real-life language use.

The analysis of the third and fourth sections of the reports revealed that the types of activities, methods, practices and assessment are not conducive to critical thinking 
implementation at the level of secondary-school EFL classes. Besides, the fifth and the last sections enclosed summarized pieces of advice concerning the teaching methodologies and classroom practices of the observed teachers. Once again, this section confirms the absence of methods, tasks, and strategies that help implement and foster critical thinking in classrooms.

\section{Interview}

To support the hypothesis that critical thinking methods and strategies are absent from classrooms. A semi-structured interview was held with the teacher trainer, whose reports have been analyzed previously in this study. The interview aimed at digging deeper into the current study case and elicit information on the current classroom teaching practices. The interview also concentrates on how the teacher trainer helps teachers adopt an effective methodology to foster critical thinking in EFL classes. The researcher designed the interview questions to get more details about the reasons behind teachers' reticence about enhancing critical thinking skills among EFL learners.

According to the teacher trainer, one of the teachers' responsibilities in EFL classes is to encourage critical thinking among learners. In this vein, teachers play a vital role in enhancing this skill by involving learners in various collaborative and problem-solving tasks. During his observation sessions, the interviewee expected EFL teachers to adopt the $21^{\text {st }}$-century skills methodology; however, most of them use the traditional way of teaching.

Concerning the reasons behind teachers' hesitation to use active learning strategies to foster learners' critical thinking, the teacher trainer's answers revolved around the obstacles encountered by teachers during their teaching. According to him, teachers do not use collaborative and group work activities because they are time-consuming and engender much noise in overcrowded classrooms. In addition, teachers are so frustrated about completing the lengthy programs before the baccalaureate exam that they forget the importance of integrating those active learning strategies and problem-solving tasks.

According to the interviewee, teachers should focus more on designing a significant number of critical thinking activities and engage learners in problem-solving tasks that require higher-order thinking skills, such as evaluating, synthesizing and analyzing data. Teachers should also use thought-provoking questions to trigger their curiosity.

The interviewee's responses concerning the teachers' training on the strategies that foster critical thinking were affirmative. During each classroom visit, the interviewee provided teachers with some directives and guidance on adopting challenging behaviors to develop learners' thinking skills, like designing problem-solving situations in which learners exploit their higherorder skills to solve the problem. Most of the teacher trainer's advice to the visited teachers revolved around using thought-provoking questions rather than yes/no and reference questions and increasing learners' motivation to engage them and encourage them to interact with each other. The teacher trainer also talked about the seminars and workshops on active learning methods, critical thinking enhancement and learner-centeredness teachers attended during the 2019-2020 school year. 


\section{Discussion}

Whether critical thinking is given importance in Algerian EFL classrooms or not is the main concern of the current study. Therefore, two tools were used to investigate this question: a teacher trainer's classroom observation reports and an interview with the same teacher trainer. To give more credibility to the current research results, the researcher targeted the reports of the most experienced teachers. Those reports contained much information about the physical teaching environment and the concerned teachers' classroom practices. After being analyzed by the researcher, a variety of results was collected.

The visited teachers had mostly overcrowded classes of different levels, first, second and third-year classes. Such a classroom environment favors teacher-centredness where lecturing dominates every lesson. Consequently, individual work is predominant, and pair/group work is avoided. Such a method inhibits the use of communicative and active learning strategies because of (according to the teacher trainer) the noise they engender in those overcrowded classrooms. Therefore, the lack of group work, active learning, and problem-solving activities hinder communication, collaboration, creativity, and critical thinking enhancement.

The teacher trainer's reports contain many remarks about the types of questions the visited teachers use in their lessons and exams. The majority of those questions are based on knowledge recall and do not necessitate any higher-order thinking skills. Most of the tasks assigned to learners are coursebook-based and are rarely adapted to challenge learners or fit their profiles. The proposed tasks also contain reference questions and do not trigger any considerable curiosity; therefore, learners are not encouraged to exploit their thinking potential, i.e., critical thinking.

The interview conducted with the teacher trainer indicates that teachers are well trained on the methods and strategies that foster critical thinking. Thanks to the trainer's seminars and workshops, teachers are aware of the importance of critical thinking as a vital skill that should be given its appropriate concern in EFL secondary school classes because it will undoubtedly help the Algerian learner face the $21^{\text {st }}$-century challenges and succeed in the workplace and life. When enhanced in an EFL class, critical thinking helps learners solve problems, learn better and become knowledgeable of the target language. They will manage to use their acquired language in every linguistic setting and improve their communication abilities through the four skills, namely: listening, speaking, reading and writing. However, learners develop critical thinking skills if teachers encourage them to make their own judgments and make decisions independently. Such a method could be applied in classrooms through planning tasks that gradually provoke learners' higher thinking levels.

The interview partially uncovered the responsible actors and circumstances that hinder the development of critical thinking in Algerian EFL classes. Since the teacher trainer organized workshops on modern teaching methods and techniques, teachers were supposed to apply them in their classrooms. According to the data obtained from the reports, most teachers did not, so they become responsible for such a situation since they are trained on those methods, but they do not put them into practice in classrooms. However, the discussion with the interviewee showed that the teachers' reticence about ensuring a classroom environment that helps develop critical thinking among learners is also due to other obstacles that teachers encounter, like the lengthy, 
time-consuming English programs that teachers are urged to finish before the baccalaureate exam. It is worth noting that this exam mainly tests learners' linguistic competencies rather than higher-order skills. These results show that responsibility is allocated to the actors and circumstances that are discussed above. However, teachers still have a great responsibility in this case. They should follow the syllabus designers' recommendations and do their best to "adapt" the syllabus content and employ active learning methods and techniques to help learners become critical thinkers.

The interview with the teacher trainer was meant to get a better perception of classroom practices. Its results confirmed that critical thinking remains a challenging skill for many secondary school teachers; however, with a strong will and perseverance, they could overcome such a situation and pave the way for our learners to develop their critical thinking skills.

\section{Conclusion}

Expectations do not always reflect reality. Although the Algerian English syllabus designers set clear aims, objectives and recommendations concerning the teaching approaches competency-based approach, project-based learning and learner centredness - to be used to help learners develop their critical thinking, secondary-school EFL teachers still adopt the traditional direct instruction and language content acquisition methods both in teaching and designing tests. The analysis results of the teacher trainer's classroom observation reports and interview confirmed the predominance of the traditional teaching methods and the scarcity of $21^{\text {st }}$-century teaching/learning approaches and strategies that enhance critical thinking, such as reflective, active, collaborative, communicative, creative, and problem solving-based learning. The results also revealed that teachers prefer teaching the programs linguistic content to help learners pass the baccalaureate exam in which most of its content is based on linguistic competencies and where rote recall is the key to success. Teachers also avoid using those strategies because they are time-consuming. If teachers apply them in class, they could face some time constraints and could not finish the content of the lengthy English programs, which could have bad consequences on learners' results in the baccalaureate exam.

Such findings imply that the syllabus designers' expectations for developing critical thinking skills among secondary-school learners have not been fulfilled yet. To overcome such a situation and allow our learners to possess the $21^{\text {st }}$ Century skills, the stakeholders and the teaching community should reconsider how the official exams are designed and adapt them according to the 21 st century learners' needs. In this case, our learners will be tested on higherorder skills rather than on the rote recall of knowledge.

\footnotetext{
About the author:

Meriem Baghoussi holds a Ph.D. in Didactics and Applied Linguistics from Abdelhamid Ibn Badis University, Mostaganem, Algeria. She has been teaching English in secondary school for eight years. Her research interests center around EFL teaching and Psychopedagogy. https://orcid.org/0000-0001-5694-3364
} 


\section{References}

Anderson, L. W., \& Krathwohl, D. (2001). A Taxonomy for Learning, Teaching, and Assessing: A Revision of Bloom's Taxonomy of Educational Objectives. New York: Addison Wesley Longman.

Beyer, B. K. (1987). Practical strategies for the teaching of thinking. Boston, MA: Allyn and Bacon.

Bloom, B., Englehart, M. Furst, E., Hill, W., \& Krathwohl, D. (1956). Taxonomy of educational objectives: The classification of educational goals. Handbook I: Cognitive domain. New York, Toronto: Longmans, Green.

Bloom's Taxonomy - What Is It and How It Can Be Applied Effectively to Develop Critical Thinking Skills. (2019). Retrieved from https://lsme.ac.uk/blog/blooms-taxonomy.

Choy, C., \& Cheah, P. (2009). Teacher Perceptions of Critical Thinking among Students and its Influence on Higher Education. International Journal of Teaching and Learning in Higher Education, 20, n2, 198-206.

Crowl, T.K., Kaminsky, S., \& Podell, D.M. (1997). Educational Psychology Windows on Teaching. Chicago: Brown and Benchmark Publishers.

Fasko, D. (2003). Critical Thinking: Origins, Historical Development, Future Direction. In D. Fasko (Ed.), Critical Thinking and Reasoning: Current Research, Theory and Practice (pp. 3-20). Cresskill, NJ: Hampton Press.

Fisher, R. (2002). Creative Minds: Building communities of learning for the creative age. Paper at Thinking Qualities Initiative Conference, Hong Kong Baptist University, June 2002.

Forrester, J. (2008). Thinking creatively; thinking critically. Asian Social Science, 4(5), 100-105. Gardner, H. (1993). Frames of Mind. New York: Basic Books.

Gottfredson, L. S. (1997). Mainstream Science on Intelligence: An Editorial with 52 Signatories, History, and Bibliography. Intelligence, 24 (1), 13-23.

Halonen, J. S. (1995). Demystifying Critical Thinking. Teaching of Psychology, 22 (1), 75-81.

Halpern, D. F. (1996). Thought and Knowledge: An Introduction to Critical Thinking (3rd ed.). Mahwah, NJ: L. Erlbaum Associates.

Halpern, D. F. (1998). Teaching Critical Thinking for Transfer across Domains: Disposition, Skills, Structure Training, and Metacognitive Monitoring. American Psychologist, 53(4), 449-455. https://doi.org/10.1037/0003-066X.53.4.449

Halpern, D. F. (2014). Thinking: An Introduction. In Taylor \& Francis (Eds.), Thought and Knowledge: An Introduction to Critical Thinking (5th ed.). NY, Sussex: Psychology Press.

Halpern, D. F., \& Butler, H. A. (2020). Is critical thinking a better model of intelligence? In Sternberg, R. J. (Ed.). The nature of intelligence (2nd ed.) (pp.183-196). Cambridge University Press.

Herrnstein, R.J., \& Murray, C. (1994). The Bell Curve: Intelligence and Class Structure in American Life. New York: The Free Press.

Liu, O., Frankel, L., \& Roohr, K. (2014). Assessing Critical Thinking in Higher Education: Current State and Directions for Next-Generation Assessment. Research Report. ETS RR-14-10. ETS Research Report Series. Available at: https://www.researchgate.net/publication/264774932_Assessing_Critical_Thinking_in_H igher_Education_Current_State_and_Directions_for_Next-Generation_Assessment

Magno, C. (2010). The Role of Metacognitive Skills in Developing Critical Thinking. Metacognition and Learning, 5(2), 137-142. 10.1007/s11409-010-9054-4. 
MNE (2005a). Programme of English as a Second Foreign Language, First Year Secondary School. Algeria, Algiers.

MNE (2005b). Programme of English as a Second Foreign Language, Second Year Secondary School. Algeria, Algiers.

MNE (2006). Programme of English as a Second Foreign Language, Third Year Secondary School. Algeria, Algiers.

Paul, R. W. (1993). Critical Thinking: What Every Person Needs to Survive in a Rapidly Changing World. Santa Rosa, CA: Foundation for Critical Thinking.

Ray Loree, M. (1965). Psychology of Education. New York: The Ronald Press Company.

Schoen, D. (1983). The reflective practitioner. San Francisco: Jossey-Bass.

Schug, M. (2003). Teacher-Centered Instruction: The Rodney Dangerfield of Social Studies. In Leming, J., Ellington, L., Porter-Magee, K., Where Did Social Studies Go Wrong?. The Thomas B. Fordham Foundation. Available at: https://fordhaminstitute.org/national/research/where-did-social-studies-go-wrong

Scriven, M., \& Paul, R. (1987). Defining Critical Thinking: The Foundation for Critical Thinking. Available at: https://www.criticalthinking.org/pages/defining-criticalthinking/766

Smith, H. P. (1962). Psychology in Teaching. USA: Prentice Hall. 